\title{
EP-25
}

\section{Relationship between HBV-DNA viral load and transaminase enzymes in hepatitis B patients in a low setting area}

\author{
Arum Tri WAHYUNINGSIH, Osman SIANIPAR, Adika Zhulhi ARJANA*, Rhaina KHAIRANI, Budi MULYONO
}

Department of Clinical Pathology and Laboratory Medicine, Faculty of Medicine Public Health and Nursing, Universitas Gadjah Mada, Indonesia

Introduction: Chronic hepatitis B is still an infectious disease that is a major problem in Asia. The success of antiviral therapy against hepatitis B infection has been widely supported by very sensitive laboratory tests to monitor hepatitis B virus (HBV)-DNA. However, in developing countries like Indonesia, the measurement of HBV-DNA level is still a challenge. Apart from limited access, a limited health insurance system contributes to this obstacle. Potential markers are transaminase enzymes (ALT and AST) although not all studies show a strong association. This study aims to analyze the relationship between HBV-DNA viral load and transaminase enzymes (ALT and AST) in hepatitis B patients in a low setting area.

Methods: This study was funded by Deputi Bidang Penguatan Riset dan Pengembangan, Kemenristek/BRIN. This study using observational research with secondary data from January to November 2020 in hepatitis B patients at Dr. Sardjito Hospital. This study has been approved by the Committee of Ethics Committee of the Faculty of Medicine, Public Health and Nursing (FK-KMK), Universitas Gadjah Mada.

Results: The subjects of this study were 139 hepatitis B patients. The median of HBV-DNA level was 4.56 log IU/mL (0.84-8.20 IU/ $\mathrm{mL})$. The median ALT and AST levels were 41.0 U/L (6.0-1041.0 U/L) and 43.0 U/L (13.0-1058.0 U/L), respectively. Correlation analysis showed that there was a weak but statistically significant relationship between HBV-DNA and both ALT and AST levels ( $\mathrm{r}=0.383$; $p<0.01 ; \mathrm{r}=0.334 ; p<0.01)$.

Conclusions: This study demonstrates the possibility of using transaminase enzymes to monitor hepatitis B patients in a low setting area. 